\title{
Characterization of Patients with Acute Appendicitis in the Elderly
}

\author{
Eduardo Garcia Castillo ${ }^{1}$, Pedro Rolando López Rodríguez ${ }^{2 *}$, Olga Caridad León González ${ }^{1}$, Jorge Agustín Satorre Rocha ${ }^{1}$ and \\ Luis Marrero Quiala ${ }^{1}$
}

${ }^{1}$ First Degree Specialist in General Surgery, Assistant Professor, Havana, Cuba

${ }^{2}$ Specialist in First and Second Degree in General Surgery, Assistant Professor, Consultant Professor, Assistant Researcher, Havana, Cuba

*Corresponding author: Dr. Pedro Rolando López Rodríguez, National Hospital. Continental Street No. 152 between D’Strampes Street and Goicuría Street, Havana, Cuba; Tel: +5355057119; Email: lopezp@infomed.sld.cu, pedro.rolando.lopez1942@gmail.com

Received: February 15, 2022; Accepted: February 22, 2022; Published: February 28, 2022

\begin{abstract}
In recent years, acute appendicitis is presented more frequently in geriatric age due to increased life expectancy and is associated with a higher incidence of perforation and high mortality.

Objective: To characterize the behavior of acute appendicitis in the elderly at "Enrique Cabrera" Hospital over a period of ten years.

Methods: A retrospective descriptive study was carried out by reviewing 114 medical records of patients over 60 years of age treated at "Enrique Cabrera" Hospital, who underwent an urgent surgical intervention for acute appendicitis, during the period from January 2011 and December 2020. The most important variables analyzed were: age, sex, clinical picture, operative finding, complications and biopsy reports.
\end{abstract}

Results: The age group between 60 and 69 years, male sex, predominated. Typical abdominal pain prevailed over atypical. The most frequent operative finding was uncomplicated acute appendicitis. Surgical site infection was the most common complication. There was a satisfactory response in all the operated patients.

Conclusions: Patients older than 60 years operated by Acute appendicitis were predominant in males between 60 and 69 years of age, with typical abdominal pain and classic signs of appendicitis. illness. The suppuration phase of the appendix. A favorable evolution of the patients was observed operated.

Keywords: Acute appendicitis, Older adult, Life expectancy

\section{Introduction}

The first who drew attention to inflammation of the appendix cecal and gave it the name of acute appendicitis was Vidusenen 1561. In 1886 Kronlein performed the first appendectomy for apendicitis perforated, the patient died. Later in 1887 T.G. Morton of Philadelphia performed the first successful appendectomy. In Cuba, in 1893, Dr. Francisco Plá presented a presentation at the Society of Clinical Studies of Havana, about the first case of acute appendicitis, and it was in 1900 that Dr. Enrique Fortún performed the first appendectomy.Acute appendicitis occurs in the elderly with a frequency between 5 and $10 \%$. In those under 65 years of age, mortality is $0.2 \%$, while in those over 65 years of age it is $4.6 \% .2,3$ Specifically in Cuba, the number of people aged 60 and over has varied from $11.3 \%$ in 1985 to $20.4 \%$ in 2018 and $21.3 \%$ in 2020. In 2025, Cuba will be the oldest country in America.1 Acute appendicitis in geriatric patients is a challenge for the surgeon, since this group of patients is always accompanied by comorbid conditions, so any delay in diagnosis and treatment significantly increases the already recognized high morbidity and mortality of abdominal sepsis in the elderly. In accordance with the above, the American Society of Anesthesiology (ASA), presented a classification to define surgical risk, according to the functional limitations caused by coexisting diseases. It is important to point out that when comparing the mortality curves according to the ASA classification, it is concluded that postoperative mortality is more related to coexisting diseases than to chronological age. In addition to this classification, it should be taken into account account that there is a progressive decline in the physiology of the elderly, in such a way that that the physiological reserve that is usually adequate for elective surgery may be insufficient when it comes to an emergency or a postoperative complication. The diagnosis of acute appendicitis is essentially clinical. The Examination of the abdomen is performed by areas where there is less pain. Digital rectal examination should be performed routinely. We must bear in mind that the symptoms are late and nonspecific and that the elderly have low sensitivity to pain and the febrile response is usually discreet. An atypical clinical picture is common in elderly patients.Sometimes it is difficult to establish a definitive diagnosis of acute appendicitis in the geriatric patient. With the purpose of reduce complications and mortality from this disease, it is that the following work is carried out with the objective of:characterize the behavior of acute appendicitis in adults in the "Enrique Cabrera" Hospital over a period of ten years. 


\section{Methods}

An observational, descriptive longitudinal study was carried out retrospectively in the period between January 2011 and December 2020. The patients were studied from their admission until hospital discharge. Universe and sample. The universe was made up of all patients over 60 years of age who underwent surgery for acute appendicitis at the "Enrique Cabrera" General Teaching Hospital, with a total of 114 cases. It was not necessary to use a sampling method, nor to calculate the sample size since we refer toe total number of patients over 60 years operated for acute appendicitis. Inclusion criteria. Patients older than 60 years intervened surgically for acute appendicitis.

Data processing and analysis. patient information operated for acute appendicitis was obtained from the medical records of the General Surgery Service of the "Enrique Cabrera" Hospital and then transferred to a data collection form that was subsequently processed and analyzed with the Microsoft Office Excel 2010 program. The results were expressed through descriptive statistics in absolute frequencies, percentages and arithmetic mean Ethical parameters. The principles referring to the code of ethics in accordance with the Declaration of Helsinki. It was guaranteed security and confidentiality of the information, clarifying that the data derived from the research would be used for scientific purposes. The study was approved by the Hospital Ethics Committee.

\section{Results}

As can be seen in Table 1, the age group was comprised of between 60 and 69 years with $64.9 \%$. The male sex was the one with the highest incidence with $54.4 \%$.

Abdominal pain was the symptom present in $100 \%$ of the patients. patients, typical abdominal pain prevailed in 62 of them (54.4\%), only 18 had fever. There were 94 with positive Blomberg's sign, 80 cases (70.2\%) had a painful Mc Burney point, only six had tachycardia, all of which is shown in Table 2.

Table 3 shows us that in the 100 leukograms recovered from the medical records, leukocytosis was observed in $78 \%$ of $78 \%$. No we were able to retrieve the results of fourteen leukograms in the medical records. In all cases where it was possible to perform computerized axial tomography, the diagnosis was positive.

Most of the patients assessed preoperatively by the fitness classification of the American Society of Anesthesiology corresponded

Table 1: Distribution of patients over 60 years operated.

\begin{tabular}{|l|c|c|c|c|c|c|}
\hline \multirow{2}{*}{ Age } & \multicolumn{2}{|c|}{ Male } & \multicolumn{2}{c|}{ Female } & \multicolumn{2}{c|}{ Total } \\
\cline { 2 - 7 } & No. & $\%$ & No. & $\%$ & No. & $\%$ \\
\hline $60-69$ & 36 & 31,6 & 38 & 33,3 & 74 & 64,9 \\
\hline $70-79$ & 20 & 17,5 & 10 & 8,8 & 30 & 26,3 \\
\hline $80-89$ & 6 & 5,3 & 4 & 3,5 & 10 & 8,8 \\
\hline 90 or more & - & - & - & - & - & - \\
\hline Total & 62 & 54,4 & 52 & 45,6 & 114 & 100,0 \\
\hline
\end{tabular}

Sources: Information obtained from medical records. to ASAII 80 cases (70.2\%), which is observed in Table 4.

Table 5 shows that the most common anatomical-pathological diagnosis frequent was suppurative appendicitis in 74 patients $65.0 \%$. In six of them confirmed appendiceal gangrene 5.2\%.

Table 2: Distribution according to clinical picture.

\begin{tabular}{|c|c|c|}
\hline Clinical picture & $N=114$ & $\%$ \\
\hline \multicolumn{3}{|l|}{ Symptoms } \\
\hline Typical abdominal pain & 62 & 54,4 \\
\hline Atypical abdominal pain & 52 & 45,6 \\
\hline Nausea & 36 & 31,6 \\
\hline Vomiting & 40 & 35,1 \\
\hline Fever & 18 & 15,8 \\
\hline Chills & 2 & 1,8 \\
\hline Diarrhea & 2 & 1,8 \\
\hline Constipation & 2 & 1,8 \\
\hline Anorexia & 8 & 7,0 \\
\hline \multicolumn{3}{|l|}{ Signs } \\
\hline Tachycardia & 6 & 5,3 \\
\hline RHA decreased & 3 & 2,6 \\
\hline Blomberg's sign & 94 & 82,4 \\
\hline Abdominal contracture & 20 & 17,5 \\
\hline Holman's sign & 44 & 38,6 \\
\hline Painful Mc Burney point & 80 & 70,2 \\
\hline Cope and Chapman sign & 8 & 7,0 \\
\hline Rowsing's sign & 6 & 5,3 \\
\hline Lanz sore spot & 8 & 7,0 \\
\hline $\begin{array}{l}\text { Pathological digital rectal } \\
\text { examination }\end{array}$ & 8 & 7,0 \\
\hline Vaginal touch & 3 & 2,6 \\
\hline
\end{tabular}

Source: Information obtained from medical records.

Table 3: Distribution of complementary.

\begin{tabular}{|l|c|c|}
\hline Complementary & No. & \% \\
\hline Leukocytosis with shift to the left & $78 / 100$ & 78,0 \\
\hline Positive abdominal ultrasound & $4 / 38$ & 10,5 \\
\hline Computerized axial tomography & $4 / 4$ & 100,0 \\
\hline Pathological urine & $20 / 62$ & 32,2 \\
\hline
\end{tabular}

Source: Information obtained from medical records.

Table 4: Distribution according to physical status classification by the American Society of Anesthesiology.

\begin{tabular}{|l|c|c|}
\hline ASA & No. & \% \\
\hline I & 8 & 7,0 \\
\hline II & 80 & 70,2 \\
\hline III & 26 & 22,8 \\
\hline IV & - & - \\
\hline Total & 114 & 100,0 \\
\hline
\end{tabular}

Source: Information obtained from medical records. 
Table 5: Distribution according to anatomo-pathological stages of inflammation of the cecal appendix.

\begin{tabular}{|l|c|c|}
\hline Biopsy & No. & \% \\
\hline Catarrhal & 8 & 7,0 \\
\hline Phlegmonous or suppurative & 80 & 70,2 \\
\hline Gangrenous & 26 & 22,8 \\
\hline Normal & -- & -- \\
\hline Total & 114 & 100,0 \\
\hline
\end{tabular}

Source: Information obtained from medical records.

\section{Discussion}

Acute appendicitis occurred more frequently in patients aged between 60 and 69 years, which coincides with that reported by other authors [1,2]. The lower frequency in ages older than 69 years is related to appendicular atrophy due to the involution of the lymphoid tissues of the appendix $[3,4]$. In the study, the incidence of the disease prevailed in the sex masculine with respect to the feminine. In the reviewed literature, supports that from the sixth decade of life the difference with regarding sex, it ceases to manifest itself [5-7]. The physiological changes that occur with aging modify the functioning of each organ, an example of this is the perception of pain, which is usually less marked with increasing age, the same happens with fever, due to depression senile immune system called immunosenescence. In our patients, the most important symptom was pain. abdominal, different from the younger ones, in which if thesequence of the appearance of pain, first visceral and then somatic. When diarrhea or constipation is present in the clinical picture, as occurred in two patients in the study, it is related to pelvic or retroileal appendicitis where appendicitis, due to its unusual position near the rectum, generates said symptom.. On physical examination it was found that the signs considered cardinal for the diagnosis of acute appendicitis as they are the sign of Blomberg, painful Mc Burney point and others were manifested, but in a lower frequency than that presented in young people, which coincides with other studies reviewed [8-11]. The above is explained because the perception of pain decreases, due to The diseases Concomitant cardiovascular events that limit the cardiovascular response, such as increased heart rate. Regarding the laboratory tests, the leukogram reported a acceptable sensitivity to corroborate the suspected diagnosis of inflammatory process of the appendix. The use of abdominal ultrasound is not a routine indication for the diagnosis of acute appendicitis, but it was performed in most patients, as an aid to the differential diagnosis. The anatomical-pathological study of the appendix showed advanced stages of acute appendicitis, suppurative in most of the 57 patients who underwent surgery. The rate of appendiceal perforation (including perforation and gangrene) was low in the study compared to other investigations reporting rates from $30 \%$ to $70 \%$. 2,9 Perforation of the appendix is the single most important predictor of mortality and late diagnosis is the main cause of this. The most common postoperative complication was site infection. operative, which coincides with other studies such as that of González E. and others [12,13]. Study morbidity was low and mortality nil, other sources literature report it below $1 \%$. In our study, showed a satisfactory postoperative evolution of the patients. Acute appendicitis is a disease that occurs in the elderly patient with attenuated symptoms due to involution of the lymphoid tissues of the appendix, in addition to the physiological changes that occur with aging, which they modify the functioning of each organ [14-16]. In 2025, Cuba will be the oldest country in America and the sagacity and experiences of our surgeons in the diagnosis of this disease, morbidity and mortality will be very low or zero.

\section{Conclusions}

Patients over 60 years of age who underwent surgery for acute appendicitis were predominantly male, between 60 and 69 years of age, with typical abdominal pain and classic signs of the disease. The suppuration phase of the appendix was mostly confirmed. A favorable evolution of the patients was observed

\section{Conflicts of Interest}

The authors declare no conflicts of interest.

\section{Author Contributions}

Pedro Rolando Lopez Rodríguez: he reviewed clinical histories and searched for bibliography. He chose the sampling method selecting the study population and analyzed and discussed the table content. Olga Caridad León González: Helped in the review of medical records and search literature, performed statistical processing, calculated arithmetic mean and standard deviation of quantitative variables. Jorge Agustin Satorre Rocha: Performed the statistical processing, calculated and interpreted the chi-square and associated variables according to Duncan's docima. Eduardo Garcia Castillo: He reviewed the literature on the subject looking for data worldwide epidemiological data, designed the study methodology, classified the research, processed the information and limited the bibliographical references according to Vancouver standards. He wrote the document. Luis Marrero Quiala: He reviewed the literature on the subject looking for data worldwide epidemiological data, designed the study methodology, classified the research, processed the information and limited the bibliographical references according toVancouver standards. He helped draft the document.

\section{Reference}

1. Bouza PG, Villoch BR, Placencia DO, Sosa TI (2021) Calidad de la atención al anciano en dos policlínicos del municipio de Santiago de Cuba. Rev MEDISAN 25: 51-65.

2. Pol Herrera PG,López Rodríguez PR, León González OC, Cruz Alonso JR, Satorre Rocha JA (2014) Evaluación postoperatoria de pacientes de la tercera edad con el diagnóstico de la apendicitis aguda.Rev Cubana Cir 53: 1-8.

3. Rodríuguez FZ (2019) Tratamiento de la Apendicitis Aguda. Rev Cubana Cir 58: $1-12$.

4. Lin KB, Chan CL, Yang NP, Lai RK, Liu YH et al.(2015) Epidemiology of appendicitis and appendicectomy for the low-income population in Taiwan.

5. Durán MV, Pino DV, Tallón AL, Pareja CF (2018) Protocolo multidisciplinar sobre la atención del paciente con apendicitis aguda.

6. Wray CJ, Kao LS, Millas SG.(2013) Acute appendicitis: Controversies in Diagnosis and Management. Curr Probl Surg 50: 54-86. [crossref]

7. Roesch DF, Pérez-Morales AG, Romero-SG, Remes-Troche JM, Jiménez-García VA.(2012) Nuevos paradigmas en el manejo de la apendicitis. Cir gen 34: 143-9.

8. Lin KB, Chan CL, Yang NP, Lai RK, Liu YH, et al.(2015) Epidemiology of appendicitis and appendicectomy for the low-income population in Taiwan. BMC Gastroenterology 15: $13 \mathrm{p}$ [crossref] 
9. Souza-Gallardo LM, Martínez-Ordaz JL.(2017) Tratamiento de la apendicitis aguda. Rev Med Inst Mex Seguro Soc 55: 76-81.

10. Ruffolo C, Fiorot A, Pagura G, Antoniutti M, Massani M,(2013). Acute appendicitis: what is the gold standard of treatment? World J Gastroenterol19: 8799-8807.

11. Rodríguez FZ. (2019) Consideraciones Urgentes en torno al diagnóstico de la Apendicitis aguda Rev Cubana Cir 57: 1-6.

12. Melendez Flores JE, Cosio Dueñas H, Sarmiento Herrera WS (2019) Sensibilidad y especialidad de la Escala de Alvarado en el diagnóstico de pacientes atendidos por apendicitis aguda en hospitales de Cusco.Horiz Med 19: 8-12.
13. González E, Huespe P, Oggero S, Dietrich A, Campana JP, et al. (2017) Apendicitis aguda en adultos: tratamiento en un Hospital Universitario. Acta Gastroenterol Latinoam 47: 53-7.

14. Bulian DR, Kaehler G, Magdeburg R, Butters M, Burghardt J, Albrecht R, et al. (2017) Analysis of the First 217 Appendectomies of the German NOTES Registry. Ann Surg 265: 534-538.

15. Similles C, Symeonides P, Shorthouse AJ, Tekkis PP. (2010) A meta-analysis comparing conservative treatment versus acute appendectomy for complicated appendicitis (abscess or phlegmon). Surgery 147: 818-829 [crossref]

16. Gandy RC, Wang F. (2016) Should the non-operative management of appendicitis be the new standard of care? ANZ J Surg 86: 228-231.

\section{Citation:}

Castillo EG, López Rodríguez PR, León González OC, Satorre Rocha JA, Quiala LM (2022) Characterization of Patients with Acute Appendicitis in the Elderly. Sur Res Rep Volume 4(1): 1-4. 